\title{
An Investigation of the Dark Formation of Nitrous Acid in Environmental Chambers
}

\author{
JAMES N. PITTS, JR.,* EUGENIO SANHUEZA, $†$ \\ ROGER ATKINSON, WILLIAM P. L. CARTER, \\ ARTHUR M. WINER, GEOFFREY W. HARRIS, $\ddagger$ \\ and CHRISTOPHER N. PLUM 1
}

\begin{abstract}
The formation of nitrous acid (HONO) in the dark from initial concentrations of $\mathrm{NO}_{2}$ of 0.1-20 ppm in air, and the concurrent disappearance of $\mathrm{NO}_{2}$, were monitored quantitatively by UV differential optical absorption spectroscopy in two different environmental chambers of ca.4300. and 5800.L volume (both with surface/volume ratios of $3.4 \mathrm{~m}^{-1}$ ). In these environmental chambers the initial HONO formation rate was first order in the $\mathrm{NO}_{2}$ concentration and increased with the water vapor concentration. However, the HONO formation rate was independent of the NO concentration and relatively insensitive to temperature. The initial pseudo-first-order consumption rate of $\mathrm{NO}_{2}$ was $(2.8 \pm 1.2) \times 10^{-4} \mathrm{~min}^{-1}$ in the 5800-L Teflon-coated evacuable chamber and $(1.6 \pm$ $0.5) \times 10^{-4} \mathrm{~min}^{-1}$ in a $4300-\mathrm{L}$ all-Tefion reaction chamber at ca.300 $\mathrm{K}$ and ca.50\% $\mathrm{RH}$. The initial HONO yields were ca.40-50\% of the $\mathrm{NO}_{2}$ reacted in the evacuable chamber and ca.10-30\% in the all-Tefion chamber. Nitric oxide formation was observed during the later stages of the reaction in the evacuable chamber, but ca.50\% of the nitrogen could not be accounted for, and gas phase $\mathrm{HNO}_{3}$ was not detected. The implications of these data concerning radical sources in environmental chamber irradiations of $\mathrm{NO}_{\mathbf{x}}$ organic-air mixtures, and of HONO formation in polluted atmospheres, are discussed.
\end{abstract}

\section{Introduction}

The photolysis of nitrous acid (HONO) in the actinic UV region [1]

$$
\mathrm{HONO}+\mathrm{h} \nu(\lambda \sim 290-400 \mathrm{~nm}) \rightarrow \mathrm{OH}+\mathrm{NO}
$$

is an important process in urban atmospheres and in smog chamber irradiations since it produces the $\mathrm{OH}$ radical, a key participant in the 
formation of photochemical smog [2-4]. During daylight hours or during environmental chamber irradiations, HONO is formed largely by the reaction of $\mathrm{OH}$ radicals with $\mathrm{NO}$ [5].

$$
\mathrm{OH}+\mathrm{NO} \stackrel{\mathrm{M}}{\rightarrow} \text { HONO }
$$

This reaction, when balanced by its rapid photolysis via reaction (1), leads to a steady-state concentration of $\mathrm{HONO}$ and no net production of $\mathrm{OH}$ radicals. However, if $\mathrm{HONO}$ is also formed by some nonphotolytic, nonradical reaction, then its subsequent rapid photolysis would represent a net source of $\mathrm{OH}$ radicals both in the atmosphere during the period around sunrise [4] and during the initial stages of environmental chamber irradiations $[6,7]$.

Recently we have used long path $(0.8-2.3 \mathrm{~km})$ UV differential optical absorption spectroscopy (DOAS) to show that HONO can accumulate up to levels of ca.8 ppb at night in urban areas such as Los Angeles $[4,8]$ and can remain at levels above $6 \mathrm{ppb}$ for as long as $5 \mathrm{~h}[4]$. However, it is not known at the present time to what extent this nighttime increase in HONO is due to its homogeneous [9] or heterogeneous formation from $\mathrm{NO}_{2}$ (or other nitrogenous compounds) present in the atmosphere, direct emissions from automobiles [10], or some combination of these processes.

In environmental chamber systems, HONO photolysis is believed to contribute, at least in part, to the excess rate of formation of radicals characteristic of those systems [6,7], which complicates the use of environmental chamber data for testing computer kinetic models of photochemical smog formation [11]. In particular, in a series of environmental chamber experiments designed to measure $\mathrm{OH}$ radical levels in $\mathrm{NO}_{x}$-air irradiations, we observed an initial, rapidly-decaying radical source $[6,7]$. This was almost certainly due to the photolysis of initially present HONO, since direct in situ spectroscopic measurements of HONO using the DOAS technique agreed well with values calculated to fit the observed $\mathrm{OH}$ radical concentration-time profiles [7].

The initial presence of HONO in our environmental chamber experiments was not unexpected, since it had previously been observed to be formed from high concentrations of $\mathrm{NO}$ and $\mathrm{NO}_{2}$ in humid air $[12,13]$. However, the amount of HONO formed prior to irradiation in our 5800-L evacuable chamber appeared to increase with the $\mathrm{NO}_{2}$ concentration, the relative humidity and the temperature, but be independent of (or indeed decrease with) the initial NO concentration [7]. These observations showed that the heterogeneous reaction

$$
\mathrm{NO}+\mathrm{NO}_{2}+\mathrm{H}_{2} \mathrm{O} \stackrel{\text { wall }}{\longrightarrow} 2 \mathrm{HONO}
$$


could not be responsible for this observed formation of HONO under these conditions, but suggested that a reaction of $\mathrm{NO}_{2}$ with water was occurring [7].

$$
2 \mathrm{NO}_{2}+\mathrm{H}_{2} \mathrm{O} \stackrel{\text { wall }}{\longrightarrow} \mathrm{HONO}+\mathrm{HNO}_{3}
$$

In any case, the photolysis of initially present HONO cannot be the entire radical source, since a continuous chamber radical source was also observed throughout $\mathrm{NO}_{\boldsymbol{x}}$-air irradiations, long after any initially present HONO was removed by photolysis [7]. If the photolysis of HONO is also the cause of this chamber radical source, the HONO must be continuously formed during the irradiation by a process other than reaction (2).

Recently, Sakamaki, Hatakeyama, and Akimoto [14] have also observed that $\mathrm{HONO}$ is formed in the dark from $\mathrm{NO}_{2}$, at initial concentrations of ca.1-20 ppm in air, in a 6065-L Teflon-coated environmental chamber at a rate which could contribute, at least in part, to the continuous radical source we had earlier observed in $\mathrm{NO}_{x^{-a i r}}$ irradiations. Their data also showed that the observed HONO did not result from reaction (3). This observation is consistent with previous studies of this reaction which showed it to be ton slow to be of importance in the part-per-million (ppm) concentration regime of interest here [12,13,15]. Rather, Sakamaki, Hatakeyama, and Akimoto [14] attributed the formation of HONO to the heterogeneous hydrolysis of $\mathrm{NO}_{2}$, which they wrote as the nonstoichiometric reaction ( $\left.4^{\prime}\right)$.

$$
\mathrm{NO}_{2}+\mathrm{H}_{2} \mathrm{O} \rightarrow \stackrel{\text { wall }}{\rightarrow} \mathrm{HONO}
$$

Interestingly, gas phase $\mathrm{HNO}_{3}$ was not observed, although nitric oxide was formed at an ca.10\% yield [14].

Previous studies of the hydrolysis of $\mathrm{NO}_{2}$ were conducted at higher surface/volume (S/V) ratios, and differ on the rate of reaction and reaction order in $\mathrm{NO}_{2}$. Thus England and Corcoran [16] studied the $\mathrm{NO}_{2}-\mathrm{H}_{2} \mathrm{O}$ system at $\mathrm{NO}_{2}$ concentrations from $15.5-46.5 \mathrm{ppm}$ and water vapor concentration $\leqslant 1.5 \times 10^{4} \mathrm{ppm}$ ( $40 \%$ relative humidity). They observed that the initial rate of disappearance of $\mathrm{NO}_{2}$ was first order with respect to the water vapor concentration but was greater than first order with respect to $\mathrm{NO}_{2}$. They also determined, by use of two Pyrex reactors with $\mathrm{S} / \mathrm{V}$ ratios of 35.5 and $120 \mathrm{~m}^{-1}$, that the rate of reaction was independent of the $S / V$ ratio. Nitric oxide was the only product actually detected, at concentrations corresponding to ca. $30 \%$ of the $\mathrm{NO}_{2}$ consumed.

More recently Lee and Schwartz [17] studied the reaction of gaseous $\mathrm{NO}_{2}$ with liquid water at low $\mathrm{NO}_{2}$ partial pressures. The observed products were equal amounts of nitrite and nitrate. At a steady-state 
aqueous phase concentration of $\mathrm{NO}_{2}$ the rate of reaction was observed to be second order with respect to the $\mathrm{NO}_{2}$ pressure [17].

We report here results of an extensive series of measurements of HONO formation from $\mathrm{NO}_{2}$ at concentrations down to ca.100 ppb, levels commonly observed in urban atmospheres. These experiments were conducted in the dark in two different environmental chambers, employing the sensitive, in situ, DOAS technique to concurrently monitor ppb levels of $\mathrm{HONO}$ and $\mathrm{NO}_{2}$. These results lead to a better understanding of the characteristics and range of variability of this important process in environmental chambers, and its relevance to polluted ambient atmospheres.

\section{Experimental}

The majority of the experiments were carried out in the SAPRC 5800-L evacuable, thermostatted, environmental chamber (EC) [18]. This cylindrical chamber is Teflon-coated with quartz end-windows mounted in a Teflon-coated aluminum grid [18]. It has a diameter of $1.37 \mathrm{~m}$ and a length of $3.96 \mathrm{~m}$, yielding a $\mathrm{S} / \mathrm{V}$ ratio of $3.4 \mathrm{~m}^{-1}$, with the window surfaces contributing ca.18\% of the total surface area. Experiments were carried out at temperatures ranging from 283-323 $\mathrm{K}$ at a relative humidity $(\mathrm{RH})$ of $50 \%$, although several experiments were carried out at lower and higher $\mathrm{RH}$. Initial $\mathrm{NO}$ and $\mathrm{NO}_{2}$ levels ranged from 0 to ca.20 ppm.

Between experiments the chamber was evacuated for several hours (generally overnight) to $\leqslant 2 \times 10^{-5}$ torr. The chamber was then filled with pure air $[18,19]$ of the desired humidity (determined by wet bulb/dry bulb measurements) to approximately 730-torr total pressure, and then $\mathrm{NO}_{2}$ and $\mathrm{NO}$ (if any) were flushed by a stream of ultrahigh purity nitrogen into the chamber from a ca.5-L bulb attached to a vacuum gas-handling line. The $\mathrm{NO}$ was purified by passage through a trap containing activated Linde Molecular Sieve $13 \mathrm{X}$, and $\mathrm{NO}_{2}$ was prepared by reaction of this purified NO with 1 atm of ultrahigh purity $\mathrm{O}_{2}$, which had also been passed over 13X Molecular Sieve. The contents of the chamber were mixed with two stirring fans for a minimum of five minutes after addition of $\mathrm{NO}$ and $\mathrm{NO}_{2}$, and the chamber was maintained at the desired temperature by means of the chamber's heating/cooling system [18].

Nitrous acid and $\mathrm{NO}_{2}$ were monitored by DOAS using a multiple pass White-type optical system (3.77-m base path) arranged along the longitudinal axis of the chamber. A 75-W Xe light source was focused by a spherical mirror to match the focal length of the multiple pass optical system. Forty passes through the chamber, and thus a $150.8-\mathrm{m}$ 
total path length, were used, leading to a sensitivity of ca.5 ppb for $\mathrm{HONO}$ and ca.20 ppb for $\mathrm{NO}_{2}$.

After transmission through the chamber, the beam was focused on the entrance slit of a $0.3-\mathrm{m} \mathrm{McPherson}$ spectrograph equipped with a 600 groove $\mathrm{mm}^{-1}$ grating (dispersion ca. $4 \mathrm{~nm} \mathrm{~m} \mathrm{~mm}^{-1}$ ). A thin metal disc (20-cm diameter), rotating at $1.1 \mathrm{~Hz}$, with 100 radial slits (100$\mu \mathrm{m}$ wide, ca.16-mm spacing) was placed in the exit focal plane. The light intensity passing through a slit was monitored by a photomultiplier (EMI 9659Q), and the signal in each of 350 channels measured for ca.20 $\mu$ s. The signals were then digitalized ( 12 bits) and stored by a computer (DEC MINC-11/23) to average the scans and to permit spectral deconvolution and calculation of optical densities. With this arrangement a 40-nm segment of the dispersed spectrum was scanned repetitively in any specific spectral region. In these studies the nearUV region from ca.335 to $375 \mathrm{~nm}$ was utilized since the absorption spectra of $\mathrm{HONO}$ and $\mathrm{NO}_{2}$ both show distinct structure in this wavelength range.

A more limited set of experiments was carried out in a ca.4300-L indoor all-Teflon (FEP, 2 mil thickness) chamber (ATC) also equipped with an in situ, multiple pass optical system interfaced to a monochromator-photomultiplier combination for DOAS. The base path of this optical system was $2.15 \mathrm{~m}$, corresponding to a total path length of $102.5 \mathrm{~m}$ for 48 passes. The operating conditions and techniques used were essentially identical to those described above for the 5800$\mathrm{L}$ evacuable chamber. The $\mathrm{S} / \mathrm{V}$ of $3.4 \mathrm{~m}^{-1}$ for this chamber was identical to that for the $5800-\mathrm{L}$ evacuable chamber.

In addition to measurements of $\mathrm{HONO}$ and $\mathrm{NO}_{2}$ by DOAS, $\mathrm{NO}$ and $\left(\mathrm{NO}_{x}-\mathrm{NO}\right)$ were measured directly after the injection with a commercial chemiluminescence NO-NO ${ }_{x}$ analyzer (TECO Model 14B). For selected runs NO was monitored with a SAPRC-built chemiluminescence NO monitor which had a detection sensitivity of ca.1 ppb. In one evacuable chamber run (EC-784) a search was made for gas phase $\mathrm{HNO}_{3}$ by long path Fourier transform infrared (FTIR) absorption spectroscopy using a pathlength of $80 \mathrm{~m}$. The $\mathrm{HNO}_{3}$ detection limit for this technique was ca. $40 \mathrm{ppb}$ under the conditions employed.

\section{Results}

\section{Evacuable Chamber Studies}

As noted above, the majority of the environmental chamber experiments were conducted in the SAPRC 5800-L Teflon-coated environmental chamber. Two series of experiments, separated by over a year, 
were conducted in that chamber, and the conditions and results of these experiments are summarized in Table $I$.

In all cases HONO formation was observed, together with a disappearance of $\mathrm{NO}_{2}$, as shown, for example, in Figure 1 for run EC758. In order to assess whether background offgassing of HONO could be a contributing factor, one experiment (EC-778) was carried out with the evacuable chamber filled with pure air alone at $50 \% \mathrm{RH}$ and $297 \mathrm{~K}$. The HONO, NO, and $\mathrm{NO}_{2}$ offgassing rates were measured and observed to be $0.001 \pm 0.0003,0.002 \pm 0.0004$, and $0.004 \pm 0.001$ ppb $\min ^{-1}$, respectively. These were generally minor compared to the observed formation or decay rates (Table I), indicating that the presence of $\mathrm{NO}_{2}$ is required for any significant HONO formation to occur.

For many of the experiments, data were obtained over reaction periods of up to 2-3 days. In the case of run EC-758, data were obtained over a period of ca.21 h and as seen in Figure 1 the HONO formation rate and the $\mathrm{NO}_{2}$ disappearance rate both decreased with the reaction time (with the former generally decreasing faster than the latter). However, within the experimental errors, the HONO formation rates and the $\mathrm{NO}_{2}$ disappearance rates were constant for up to $2-3 \mathrm{~h}$ for initial $\mathrm{NO}_{2}$ concentrations $\geqslant 350 \mathrm{ppb}$, and up to ca.24 h for experiments with initial $\mathrm{NO}_{2}$ concentrations of $\leqslant 100 \mathrm{ppb}$. Table I also gives these initial $\mathrm{HONO}$ formation and $\mathrm{NO}_{2}$ disappearance rates.

The data in Table I and Figure 1 show that during the initial stages of the experiments the stoichiometry $\left(\Delta[\mathrm{HONO}] /-\Delta\left[\mathrm{NO}_{2}\right]\right)$ is close to, though generally somewhat less than, 0.5 . However, at extended reaction times the ratio $\left(\Delta[\mathrm{HONO}] /-\Delta\left[\mathrm{NO}_{2}\right]\right)$ typically decreased, as shown by the data in Table I. While NO was also identified during these runs, significant amounts were only observed after a rather long induction peiiod. For runs where NO was monitored Table I gives the NO and HONO yields observed at the termination of the runs, together with the final amount of $\mathrm{NO}_{2}$ consumed. It can be seen from this table that the observed NO and HONO yields account for only ca. 50\% of the $\mathrm{NO}_{2}$ reacted.

The rate of HONO formation in the evacuable chamber depended to a certain extent on the previous history of the chamber. While runs with the chamber "unconditioned" (i.e., pumped for $\leqslant 1 \mathrm{~h}$ ) gave lower HONO production rates than for runs where the chamber had been pumped for $\geqslant 1 \mathrm{~h}$, the HONO formation rate was significantly higher after the chamber was cleaned by the irradiation of ca.1 torr of $\mathrm{Cl}_{2}$ in 10 torr of $\mathrm{N}_{2}$, followed by an overnight evacuation at ca. $360 \mathrm{~K}$ (see EC-765 in Table I). The HONO formation rate subsequently returned to more typical values (see EC-774 and following runs) after the chamber 
TABLE 1. Conditions and selected results of the $\mathrm{NO}_{x}-\mathrm{H}_{2} \mathrm{O}$-air experiments conducted in the SAPRC evacuable chamber.

\begin{tabular}{|c|c|c|c|c|c|c|c|c|c|c|c|c|c|}
\hline \multirow{3}{*}{$\begin{array}{l}\text { EC Run } \\
\text { Number }\end{array}$} & \multicolumn{2}{|c|}{ In1t1al } & \multirow{3}{*}{$\begin{array}{l}\text { Tempera- } \\
\text { ture } \\
\text { (X) }\end{array}$} & \multirow{3}{*}{$\begin{array}{l}\mathrm{RH} \\
(z)\end{array}$} & \multicolumn{4}{|c|}{ InItelal } & \multicolumn{5}{|c|}{ Final } \\
\hline & {$\left[\mathrm{NO}_{2}\right]$} & [so] & & & \multirow{2}{*}{$\begin{array}{l}d[\text { HONO }] / d t \\
\left(p p b n^{-1}\right)\end{array}$} & \multirow{2}{*}{\multicolumn{2}{|c|}{$\begin{array}{l}-\mathrm{d}\left[\mathrm{HO}_{2}\right] / \mathrm{dt} \\
\left(\mathrm{ppb} \mathrm{min}^{-1}\right)\end{array}$}} & \multirow{2}{*}{$\frac{d[\mathrm{HONO}] / \mathrm{dt}}{-\mathrm{d}\left[\mathrm{NO}_{2}\right] / \mathrm{dt}}$} & \multirow{2}{*}{$\begin{array}{c}t \\
(m \ln )\end{array}$} & \multirow{2}{*}{$\begin{array}{l}\Delta\left[\mathrm{NO}_{2}\right] \\
(\mathrm{ppb})\end{array}$} & \multicolumn{3}{|c|}{$\mathrm{Y} 1 \mathrm{e} 1 \mathrm{~d} / \Delta\left[\mathrm{NO}_{2}\right]$} \\
\hline & $(p p b)$ & $(p p b)$ & & & & & & & & & HONO & no & $N-10 \cos$ \\
\hline 558 & 190 & 0 & 305 & so & $0.032 \pm 0.002$ & 0.078 & \pm 0.007 & 0.42 & 204 & 15 & 0.43 & 0 & 0.57 \\
\hline 545 & 354 & 93 & 305 & 50 & $0.069 \pm 0.004$ & & - & - & & & & & \\
\hline 546 & 360 & 920 & 305 & 50 & $0.048 \pm 0.003$ & & - & & & & & & \\
\hline 557 & 380 & 0 & 305 & 50 & $0.060 \neq 0.003$ & & - & - & & & & & \\
\hline 556 & 383 & 0 & 305 & 50 & $0.037 \pm 0.004$ & 0.10 & \pm 0.01 & 0.37 & 270 & 21 & 0.48 & - & - \\
\hline 544 & 400 & 0 & 305 & 50 & $0.064 \pm 0.004$ & & - & - & & & & & \\
\hline 564 & 590 & 187 & 305 & 50 & $0.068 \pm 0.006$ & & - & & & & & & \\
\hline 555 & 733 & 0 & 305 & 50 & $0.100 \pm 0.005$ & 0.21 & \pm 0.06 & 0.48 & 120 & 25 & 0.48 & 0 & 0.52 \\
\hline 548 & 878 & 900 & 305 & so & $0.15 \neq 0.007$ & & - & - & & & & & \\
\hline 559 & 1563 & 0 & 305 & 50 & $0.13 \pm 0.007$ & & - & - & & & & & \\
\hline 560 & 1682 & 0 & 305 & 50 & $0.13 \pm 0.006$ & & - & - & & & & & \\
\hline 549 & 1750 & 900 & 305 & 50 & $0.15 \pm 0.008$ & & - & - & & & & & \\
\hline 547 & 400 & 0 & 305 & 3 & $0.030 \pm 0.006$ & & - & - & & & & & \\
\hline 554 & 353 & 978 & 305 & 16 & $0.039 \pm 0.003$ & & - & - & & & & & \\
\hline 566 & 610 & 215 & 305 & 35 & $0.049 \pm 0.005$ & & - & - & & & & & \\
\hline 565 & 600 & 130 & 305 & 65 & $0.150 \pm 0.02$ & & - & - & & & & & \\
\hline 563 & 751 & 0 & 305 & 65 & $0.21 \pm 0.006$ & & - & - & & & & & \\
\hline
\end{tabular}


TABLE I. (continued from previous page)

\begin{tabular}{|c|c|c|c|c|c|c|c|c|c|c|c|c|c|}
\hline \multirow{3}{*}{$\begin{array}{l}\text { EC Run } \\
\text { Number }\end{array}$} & \multicolumn{2}{|c|}{ Intelal } & \multirow{3}{*}{$\begin{array}{c}\text { Tempera- } \\
\text { ture } \\
\langle\mathrm{x}\rangle\end{array}$} & \multirow{3}{*}{$\begin{array}{l}\mathrm{RH} \\
(\%)\end{array}$} & \multicolumn{4}{|c|}{ InItlal } & \multicolumn{5}{|c|}{ Plnal } \\
\hline & {$\left[\mathrm{NO}_{2}\right]$} & [NO] & & & \multirow{2}{*}{$\begin{array}{l}\mathrm{d}[\text { HONO]/dt } \\
\left(\mathrm{ppb} \mathrm{m}^{-1} \mathrm{a}^{-1}\right)\end{array}$} & \multirow{2}{*}{\multicolumn{2}{|c|}{$\begin{array}{l}-\mathrm{d}\left[\mathrm{NO}_{2}\right] / \mathrm{dt} \\
\left(\mathrm{ppb} \mathrm{an}^{-1}\right)\end{array}$}} & \multirow{2}{*}{$\frac{d[\text { BONO }] / d t}{d\left[\mathrm{NO}_{2}\right] / d t}$} & \multirow{2}{*}{$\begin{array}{c}t \\
(\min n)\end{array}$} & \multirow{2}{*}{$\begin{array}{l}\Delta\left[\mathrm{NO}_{2}\right\} \\
(\mathrm{ppb})\end{array}$} & \multicolumn{3}{|c|}{ Yleld/A $\left[\mathrm{NO}_{2}\right]$} \\
\hline & $(p p b)$ & $(p p b)$ & & & & & & & & & HoNo & No & $N-1038^{a}$ \\
\hline $778^{b}$ & 0 & 0 & 297 & so & $0.001 \pm 0.0003$ & -0.004 & \pm 0.001 & - & - & - & - & - & - \\
\hline 781 & 58 & 0 & 297 & 50 & $0.004 \pm 0.001^{c}$ & 0.009 & $\pm 0.002^{c}$ & 0.44 & 2565 & 27 & 0.26 & 0.19 & 0.55 \\
\hline 780 & 100 & 100 & 297 & 50 & $0.020 \pm 0.002^{c}$ & & - & - & - & - & - & - & - \\
\hline 779 & 112 & 0 & 297 & 50 & $0.012 * 0.002^{c}$ & 0.025 & $\pm 0.004^{\circ}$ & 0.48 & 1550 & 31 & 0.42 & 0.16 & 0.42 \\
\hline 782 & 160 & 0 & 297 & 50 & $0.013 \pm 0.001$ & 0.027 & \pm 0.005 & 0.48 & 2850 & 51 & 0.35 & - & - \\
\hline 759 & 281 & 0 & 297 & 50 & $0.031 \pm 0.004$ & & - & - & 1455 & 103 & 0.39 & - & - \\
\hline 763 & 354 & 0 & 297 & 50 & $0.058 \pm 0.005$ & 0.103 & \pm 0.017 & 0.56 & 390 & 40 & 0.56 & & \\
\hline 764 & 364 & -1000 & 297 & 50 & $0.052 \pm 0.006$ & & - & - & - & - & - & - & - \\
\hline 757 & 530 & 0 & 297 & 50 & $0.061 \pm 0.005$ & 0.13 & \pm 0.03 & 0.47 & 285 & 37 & 0.47 & - & - \\
\hline $765^{d}$ & $\$ 44$ & 0 & 297 & 50 & $0.123 \pm 0.009$ & 0.334 & \pm 0.015 & 0.37 & 1360 & 250 & 0.26 & - & - \\
\hline 775 & 550 & 0 & 297 & 50 & $0.056 \pm 0.006$ & & 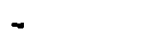 & - & - & - & - & - & - \\
\hline 753 & 580 & 0 & 297 & 50 & $0.069 \pm 0.004$ & 0.169 & \pm 0.013 & 0.41 & 360 & 61 & 0.42 & & \\
\hline $774 c^{e}$ & 763 & 0 & 297 & 50 & $0.075 \pm 0.005$ & 0.193 & \pm 0.014 & 0.39 & - & - & - & - & - \\
\hline 758 & 840 & 0 & 297 & 50 & $0.107 \pm 0.007$ & 0.28 & \pm 0.06 & 0.38 & 1315 & 261 & 0.31 & - & - \\
\hline 754 & 1080 & 0 & 297 & 50 & $0.095 \pm 0.006$ & 0.28 & \pm 0.05 & 0.34 & 1400 & 300 & 0.25 & & \\
\hline $774 \mathrm{~A}$ & 1529 & 0 & 297 & 50 & $0.207 \pm 0.013$ & 0.44 & $\neq 0.08$ & 0.47 & 1500 & 435 & 0.32 & 0.23 & 0.45 \\
\hline
\end{tabular}




\begin{tabular}{|c|c|c|c|c|c|c|c|c|c|c|c|c|c|}
\hline 761 & 2242 & 0 & 297 & 50 & $0.10 \pm 0.07$ & 0.19 & \pm 0.05 & 0.53 & 1470 & 428 & 0.26 & - & - \\
\hline 783 & 5000 & 0 & 297 & so & $0.229 \pm 0.012$ & & - & - & - & - & - & - & - \\
\hline 784 & 20000 & 0 & 297 & so & $0.806 \pm 0.013$ & & - & - & - & - & - & - & - \\
\hline 776 & 685 & 0 & $29 ?$ & 5 & $0.012 \pm 0.004$ & & - & - & 1400 & 85 & 0.27 & 0.12 & 0.60 \\
\hline 760 & 543 & 0 & 297 & 22 & $0.025 \pm 0.006$ & & - & - & 1500 & 112 & 0.31 & - & - \\
\hline 552 & 340 & 917 & 283 & 50 & $0.026 \pm 0.003$ & & - & - & - & - & - & - & 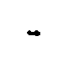 \\
\hline$\$ 53$ & 375 & 990 & 323 & 16 & $0.040 \pm 0.003$ & & - & - & - & - & - & - & - \\
\hline
\end{tabular}

- $\mathrm{N}$ loss $=\left(\Delta\left[\mathrm{NO}_{2}\right]-[\mathrm{HONO}]-[\mathrm{NO}]\right) / \Delta\left[\mathrm{NO}_{2}\right]$. Presumed to be due to formation of $\mathrm{HNO}_{3}$ on the walls (see discussion).

"Chamber offgassing rate, $d[\mathrm{NO}] / d \mathrm{t}=0.002 \pm 0.0004 \mathrm{ppb} \mathrm{min}{ }^{-1}(\Delta t=71 \mathrm{~h})$.

'Values corrected by chamber offgassing rates.

' Run performed after cleaning the chamber (see text).

- Run performed after the HONO photolysis of run 774A.

${ }^{\prime} \mathrm{HONO}$ measured by FTIR: $\left[\mathrm{HNO}_{3}\right]<40 \mathrm{ppb}$ for $[\mathrm{HONO}]=387 \mathrm{ppb}$. 


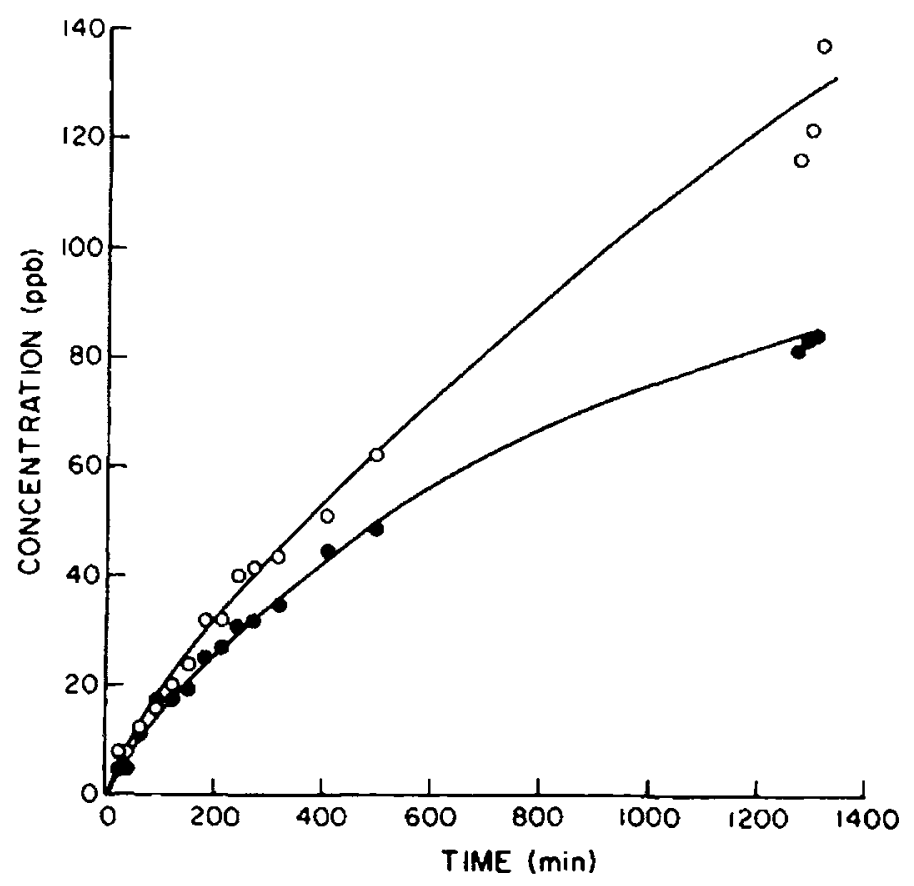

Figure 1. Plots of HONO formation and the observed amount of $\mathrm{NO}_{2}$ consumed for run EC-758. (O) $0.5 \times-\Delta \mathrm{NO}_{2},(\bullet)$ HONO.

had been conditioned by a series of $\mathrm{NO}_{x}$-air and propene- $\mathrm{NO}_{x}$-air irradiations. In order to obtain reproducible results the chamber needed to be evacuated to $\leqslant 2 \times 10^{-5}$ torr for several hours prior to an experiment, and occasional 1-h irradiations of the evacuated chamber using the 25-KW solar simulator also appeared to help in the conditioning process. Except as noted, all runs reported in Table I were carried out after the chamber had been suitably conditioned.

The initial HONO formation rates, $(d[\mathrm{HONO}] / d t)_{\text {init }}$, at ca. $50 \% \mathrm{RH}$ and 297 and $305 \mathrm{~K}$ (the conditions at which the majority of the experiments were carried out) are plotted against the $\mathrm{NO}_{2}$ concentration in Figure 2. It can be seen that the sets of data obtained at $305 \mathrm{~K}$ and $50 \% \mathrm{RH}$ and at $297 \mathrm{~K}$ and $50 \% \mathrm{RH}$ (sets of runs which were carried out more than a year apart) are, within the scatter of the data, essentially indistinguishable. This shows that, after suitable conditioning, the reaction forming HONO is reasonably reproducible in this particular chamber.

Figure 2 also shows that for the evacuable chamber, at a constant temperature and relative humidity, the plot of $1 \mathrm{n}(d[\mathrm{HONO}] / d t)_{\text {init }}$ against $\ln \left[\mathrm{NO}_{2}\right]$ is, with the scatter of the data, essentially linear with a slope close to unity. This implies that the initial HONO formation rate is approximately first order in $\mathrm{NO}_{2}$. It is also evident from the data obtained at 287 and $305 \mathrm{~K}$ and ca.50\% RH (Table I and Figure 
2) that within the scatter of the data the HONO formation rate was independent of the initial NO concentration.

Since at a given temperature and water vapor concentration the initial HONO formation rate is linearly dependent on the initial $\mathrm{NO}_{2}$ concentration, the quantity $\left\{(d[\mathrm{HONO}] / d t) /\left[\mathrm{NO}_{2}\right]\right\}_{\text {init }}$ defines an "effective" first-order rate constant which may be a function of temperature and water vapor concentration. The dependence of $\left\{(d[\mathrm{HONO}] / d t) /\left[\mathrm{NO}_{2}\right]\right\}_{\text {init }}$ on the water vapor concentration at 305 and $297 \mathrm{~K}$ is shown in Figure 3, which also shows the values of $\left\{(d[\mathrm{HONO}] / d t) /\left[\mathrm{NO}_{2}\right]\right\}_{\text {init }}$ at the other temperatures and water concentrations studied. The ratio $\left\{(d[\mathrm{HONO}] / d t) /\left[\mathrm{NO}_{2}\right]\right\}_{\text {init }}$ increases with the water vapor concentration, though the scatter of the data does not allow a conclusion to be drawn as to whether this dependence is linear or not. Additionally, as shown in Figure 3, the scatter of the data do not allow any conclusions to be drawn concerning the effects

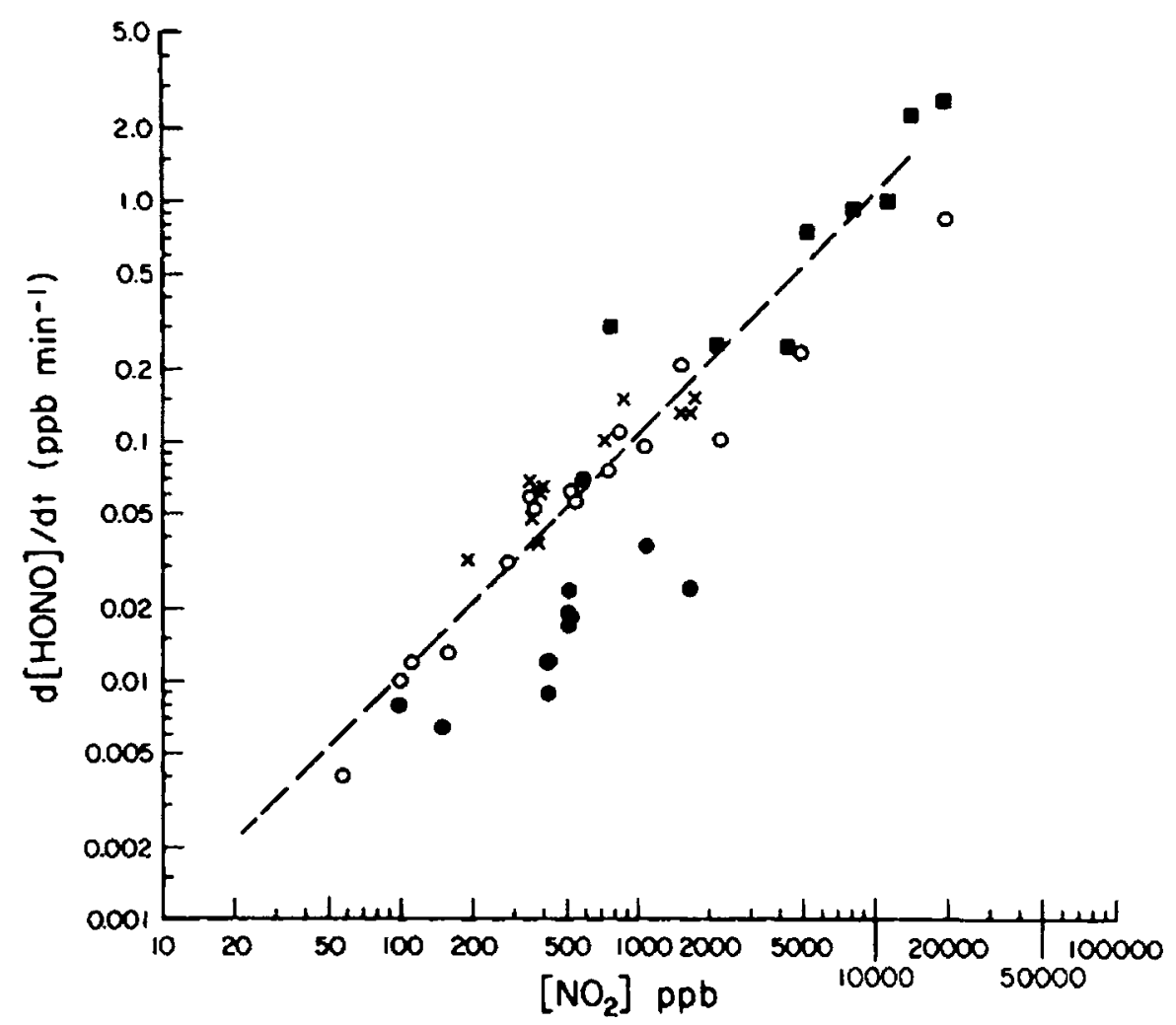

Figure 2. Plot of the HONO formation rate $d t[\mathrm{HONO}] / d t$ against the $\mathrm{NO}_{2}$ concentration for the SAPRC and NIES chambers at ca.50\% relative humidity. (X) SAPRC 5800-L evacuable chamber, $T=305 \mathrm{~K}$; (O) SAPRC 5800-L evacuable chamber, $T=297 \mathrm{~K}$; (O) SAPRC 4300-L all-Teflon chamber, $T=297 \mathrm{~K}$; (a) NIES 6065-L evacuable chamber, $T=303 \mathrm{~K}$. The dashed line is the bestfit line with unit slope through the data for the SAPRC 5800-L evacuable chamber. 


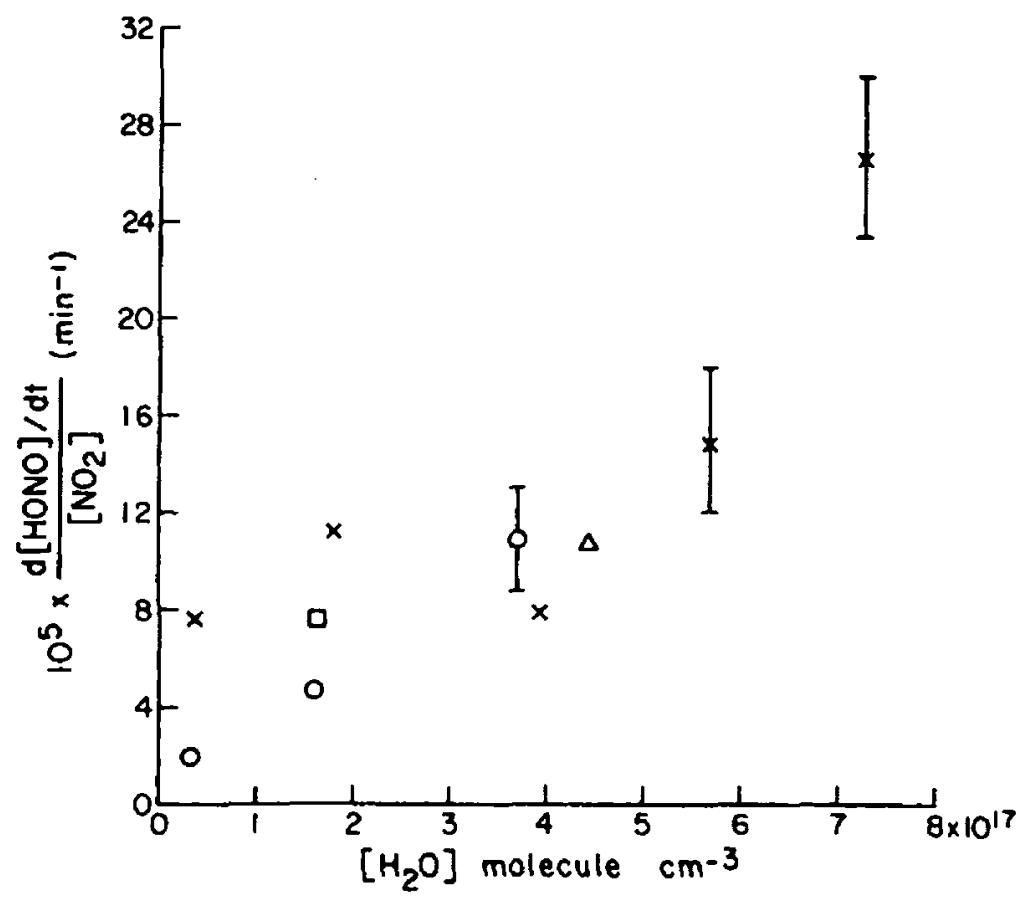

Figure 3. Plot of the HONO formation rate, normalized by the $\mathrm{NO}_{2}$ concentration, for the SAPRC 5800-L evacuable chamber against the $\mathrm{H}_{2} \mathrm{O}$ concentration at the various temperatures studied. $(\triangle) 323 \mathrm{~K},(\times) 305 \mathrm{~K}$, (O) $297 \mathrm{~K},(\square)$ $283 \mathrm{~K}$.

of temperature on the HONO formation rate. However, it is apparent that the water concentration has a larger effect on the HONO formation rate than does the temperature, at least when varied within the range employed in these experiments.

One experiment (EC-784) was carried out specifically to detect gas phase nitric acid. Using long path Fourier transform infrared (FTIR) spectroscopy, no evidence for gas phase $\mathrm{HNO}_{3}$ was obtained during this run (the detection limit for $\mathrm{HNO}_{3}$ was ca.40 ppb). Since the maximum HONO concentration observed by FTIR spectroscopy in this experiment was $387 \mathrm{ppb}$, the gas phase $\mathrm{HNO}_{3}$ concentration was at least a factor of 10 lower than that of HONO.

\section{All-Teflon Chamber Studies}

The initial reactant concentrations and the data obtained in the 4300-L Teflon chamber are given in Table II. The initial HONO formation rates are also plotted against the initial $\mathrm{NO}_{2}$ concentrations in Figure 2 to allow comparison with the results from the 5800-L evacuable chamber. The results were similar to those in the evacuable chamber in that continuous HONO formation from $\mathrm{NO}_{2}$ was observed in all cases. However, the HONO formation rates obtained in this 
TABLE II. Rates of dark HONO formation from $\mathrm{NO}_{x} / \mathrm{H}_{2} \mathrm{O} /$ air mixtures in the all-Teflon chamber.

\begin{tabular}{|c|c|c|c|c|c|c|c|c|c|}
\hline \multirow{2}{*}{$\begin{array}{l}\text { Arc } \\
\text { Rua } \\
\text { Number }\end{array}$} & \multirow{2}{*}{$\begin{array}{l}\frac{\operatorname{In} 1+1 \mathrm{a}]}{\left(\mathrm{NO}_{2}\right]} \\
(\mathrm{ppb})\end{array}$} & \multirow[b]{2}{*}{$\begin{array}{l}\text { Teep } \\
\left({ }^{\circ} \mathrm{R}\right)\end{array}$} & \multirow[b]{2}{*}{$\begin{array}{l}\mathrm{RH} \\
(\pi)\end{array}$} & \multicolumn{3}{|c|}{ Interal } & \multicolumn{3}{|c|}{ Pinal } \\
\hline & & & & $\begin{array}{l}\mathrm{d}[\text { HONO }] / d t \\
\left(\mathrm{ppb} \mathrm{min}^{-1}\right)\end{array}$ & $\begin{array}{l}-d\left[N_{2}\right] / d t \\
\left(p p b m n^{-1}\right)\end{array}$ & $\frac{d[\text { HONO }] / d t}{-d\left[\mathrm{NO}_{2}\right] / d t}$ & $\begin{array}{c}t \\
(m \mid n)\end{array}$ & $\begin{array}{r}\Delta\left[\mathrm{NO}_{2}\right] \\
(\mathrm{ppb})\end{array}$ & $\frac{\Delta \text { [HONO] }}{\Delta\left[\mathrm{NO}_{2}\right]}$ \\
\hline 4 & 1100 & 297 & 50 & $0.036 \pm 0.007$ & $0.122 \pm 0.02$ & 0.29 & 400 & 49 & 0.30 \\
\hline 6 & 537 & 297 & 50 & $0.018 \pm 0.0012$ & $0.084 \pm 0.02$ & 0.21 & 1560 & 78 & 0.33 \\
\hline 7 & 515 & 297 & 50 & $0.0235 \pm 0.0015$ & - & - & 1250 & 89 & 0.39 \\
\hline 8 & 513 & 296 & 50 & $0.017 \pm 0.001$ & $0.11 \pm 0.015$ & 0.20 & 1350 & 80 & 0.30 \\
\hline 9 & 99 & 296 & 50 & $0.0079 \pm 0.002$ & & & - & - & - \\
\hline 10 & 506 & 296 & 50 & $0.019 \pm 0.002$ & $0.065 \pm 0.01$ & 0.29 & 1150 & 66 & 0.12 \\
\hline 13 & 420 & 297 & so & $0.0087 \pm 0.001$ & $0.085 \pm 0.01$ & 0.10 & 1500 & 73 & 0.16 \\
\hline 14 & 425 & 297 & so & $0.012 \pm 0.002$ & - & - & 1300 & 50 & 0.30 \\
\hline 15 & 1680 & 298 & so & $0.024 \pm 0.002$ & - & & 1600 & 200 & 0.17 \\
\hline 16 & 150 & 298 & 50 & $0.0064 \pm 0.0004$ & - & & 3000 & 53 & 0.36 \\
\hline
\end{tabular}


chamber showed substantially more scatter than those in the 5800$\mathrm{L}$ evacuable chamber, and generally indicated lower HONO formation rates for a given $\mathrm{NO}_{2}$ concentration. In addition, Table II shows that, in contrast to the 5800-L evacuable chamber, the initial stoichiometry $\left(\Delta[\mathrm{HONO}] /-\Delta\left[\mathrm{NO}_{2}\right]\right)_{\text {init }}$ was less than 0.5 , with values as low as 0.1 (ATC-13), and that these stoichiometry values showed a significant degree of scatter.

\section{Discussion}

\section{HONO Formation in Environmental Chambers}

The initial HONO formation rates observed in the SAPRC evacuable and Teflon chambers at 50\% RH and 297-305 K, together with those reported by Sakamaki, Hatakeyama, and Akimoto [14] at much higher initial $\mathrm{NO}_{2}$ concentrations for the 6065-L evacuable chamber at the National Institute for Environmental Studies (NIES) in Japan at ca.50\% $\mathrm{RH}$ and $303 \mathrm{~K}$, are shown in Figure 2. It can be seen from this figure that the present data are qualitatively and quantitatively similar to those of Sakamaki, Hatakeyama, and Akimoto [14]. This suggests that the mechanism, at least for the initial portion of the reaction, does not change as the reactant concentrations are reduced below those employed by Sakamaki, Hatakeyama, and Akimoto [14] to levels more representative of atmospheric conditions. In particular, the data for a given chamber fall reasonably close to a line of slope $\left\{d \ln (d[\mathrm{HONO}] / d t) / d\left[\mathrm{NO}_{2}\right]\right\}_{\text {init }}=1.0$, indicating that the initial HONO formation rate is approximately first order with respect to the initial $\mathrm{NO}_{2}$ concentration throughout this concentration range.

The data for the $4300-\mathrm{L}$ all-Tefion reaction chamber fall somewhat below the line drawn through our data points obtained in the SAPRC 5800-L evacuable chamber (dashed line in Fig. 2), while the data for the NIES evacuable chamber [14] fit well on this line. Thus, as expected, the HONO formation rate from $\mathrm{NO}_{2}$ appears to be chamber dependent, with the SAPRC all-Teflon chamber being less reactive than both the SAPRC and the NIES evacuable chambers. The chamber characteristics and the averages of the observed initial first-order rates of HONO formation $\left\{(d[\mathrm{HONO}] / d t) /\left[\mathrm{NO}_{2}\right]\right\}_{\text {init }}$ and of $\mathrm{NO}_{2}$ consumption $\left\{\left(-d\left[\mathrm{NO}_{2}\right] / d t\right) /\left[\mathrm{NO}_{2}\right]\right\}_{\text {init }}$ for each of these three chambers are summarized in Table III.

The results of the present study support previous conclusions $[7,14,15]$ that HONO formation does not occur to any significant extent from the reaction

$$
\mathrm{NO}+\mathrm{NO}_{2}+\mathrm{H}_{2} \mathrm{O} \rightarrow 2 \mathrm{HONO}
$$

In particular, our data yield an upper limit for this reaction of $k_{3}<$ $6 \times 10^{-38} \mathrm{~cm}^{6}$ molecule ${ }^{-2} \mathrm{~s}^{-1}$. This is totally consistent with the value 
TABLE III. Comparison of chamber characteristics and average apparent first-order rate constants for $\mathrm{HONO}$ formation and $\mathrm{NO}_{2}$ consumption in three environmental chambers at ca. $50 \% \mathrm{RH}$ and ca. $300 \mathrm{~K}$.

\begin{tabular}{|c|c|c|c|}
\hline Chamber & $\begin{array}{l}\text { NIES } \\
\text { Evacuable }\end{array}$ & $\begin{array}{c}\text { SAPRC } \\
\text { Evacuable }\end{array}$ & $\begin{array}{c}\text { SAPRC } \\
\text { All-Teflon }\end{array}$ \\
\hline Volume (1) & 6065 & 5800 & 4300 \\
\hline Surface/volume $\left(m^{-1}\right)$ & 3.6 & 3.4 & 3.4 \\
\hline Surface ${ }^{b}$ & $\begin{array}{l}917 \text { PFA }^{c} \text { Teflon } \\
\text { coated stainless steel } \\
9 \% \text { quartz }\end{array}$ & $\begin{array}{l}\text { 82\% FEP Teflon } \\
\text { coated aluminum } \\
\sim 18 \% \text { quartz }\end{array}$ & $\begin{array}{l}\text { 100z 2-all thick } \\
\text { FEP Teflon film }\end{array}$ \\
\hline$\frac{d[\mathrm{HONO}] / d t}{\left[\mathrm{NO}_{2}\right]}\left(10^{-4} \mathrm{~min}^{-1}\right)^{\mathrm{e}}$ & $1.3 \pm 0.4^{d}$ & $1.2 \pm 0.4$ & $0.4 \pm 0.2$ \\
\hline$\frac{-\mathrm{d}\left[\mathrm{NO}_{2}\right] / \mathrm{dt}}{\left[\mathrm{NO}_{2}\right]}\left(10^{-4} \min ^{-1}\right)^{\mathrm{e}}$ & $4.4 \pm 1.1^{d}$ & $2.8 \pm 1.2$ & $1.6 \pm 0.5$ \\
\hline$\frac{d(\text { HONO }) / \mathrm{dt}^{\mathrm{e}}}{-\mathrm{d}\left(\mathrm{NO}_{2}\right) / \mathrm{dt}}$ & $0.30 \pm 0.10^{d}$ & $0.44 \pm 0.06$ & $0.21 \pm 0.08$ \\
\hline
\end{tabular}

- As described by Sakamaki, Hatakeyama, and Akimoto [14].

${ }^{b}$ Excluding IR or DOAS multi-reflection optics.

' PFA = tetrafluoroethylene-perfluoroalkyl vinyl ether copolymer.

Average of data for runs $7-13$ and $15-17$ in Table II of [14].

"Initial values.

of $k_{3}<9 \times 10^{-39} \mathrm{~cm}^{6}$ molecule ${ }^{-2} \mathrm{~s}^{-1}$ derived by Sakamaki, Hatakeyama, and Akimoto [14] for the NIES evacuable chamber, and with the value $k_{3} \leqslant 4.4 \times 10^{-40} \mathrm{~cm}^{6}$ molecule ${ }^{-2} \mathrm{~s}^{-1}$ derived by Kaiser and Wu [15] for a 0.75 -L Pyrex reaction vessel. It should be noted that our upper limit of $k_{3}<6 \times 10^{-38} \mathrm{~cm}^{6}$ molecule ${ }^{-2} \mathrm{~s}^{-1}$ corresponds to an upper limit of $k_{\cdot 3}<9 \times 10^{-19} \mathrm{~cm}^{3}$ molecule ${ }^{-1} \mathrm{~s}^{-1}$ for the reverse reaction,

$$
\mathrm{HONO}+\mathrm{HONO} \rightarrow \mathrm{NO}+\mathrm{NO}_{2}+\mathrm{H}_{2} \mathrm{O}
$$

based on the equilibrium constant $k_{3} / k_{-3}=7.0 \times 10^{-20} \mathrm{~cm}^{3}$ molecule ${ }^{-1}$ at $298 \mathrm{~K}$ [20]. The gas phase reaction $(-3)$ is this also negligible under our experimental conditions (see below).

Thus the present data indicate that reaction of $\mathrm{NO}_{2}$ with water vapor is the source of HONO in these chambers, in agreement with the conclusion of Sakamaki, Hatakeyama, and Akimoto [14]. Although the overall reaction may occur via

$$
2 \mathrm{NO}_{2}+\mathrm{H}_{2} \mathrm{O} \rightarrow \mathrm{HONO}+\mathrm{HNO}_{3}
$$

the rate determining step is first-, and not second-, order in $\mathrm{NO}_{2}$. Furthermore, $\mathrm{HNO}_{3}$ was not observed in the gas phase in either the 
present work or by Sakamaki, Hatakeyama, and Akimoto [14]. However, reaction (4) is consistent with the lack of a dependence of the HONO formation rate on the NO concentration, and also with the observation that the HONO formation rate was equal or less than half of the $\mathrm{NO}_{2}$ consumption rate.

The reverse reaction

$$
\mathrm{HNO}_{3}+\mathrm{HONO} \rightarrow 2 \mathrm{NO}_{2}+\mathrm{H}_{2} \mathrm{O}
$$

has been studied in the gas phase by Kaiser and Wu [21] and Streit et al. [22] who obtained a rate constant of $k_{-4} \simeq 1 \times 10^{-17} \mathrm{~cm}^{3}$ molecule ${ }^{-1} \mathrm{~s}^{-1}$ at room temperature. Kaiser and $\mathrm{Wu}$ [21] observed that this reaction was sensitive to surface conditions, and hence this rate constant must be considered to be an upper limit. Using this upper limit value for $k_{-4}$ and the equilibrium constant $k_{4} / k_{-4}=3.9$ $\times 10^{-21} \mathrm{~cm}^{3}$ molecule ${ }^{-1}$ [20], a value of $k_{4} \leqslant 4 \times 10^{-38} \mathrm{~cm}^{6}$ molecule ${ }^{-2}$ $\mathrm{s}^{-1}$ is obtained for the homogeneous gas phase reaction. This upper limit value for $k_{4}$ leads to HONO formation rates much lower than those observed experimentally when $\left[\mathrm{NO}_{2}\right]<1 \mathrm{ppm}$ (see Tables $\mathrm{I}$ and II) and much higher than those observed when $\left[\mathrm{NO}_{2}\right] \geqslant 5 \mathrm{ppm}$ (see Table I and [14]).

These conditions, together with the observed first-order dependence of $\mathrm{HONO}$ formation on the $\mathrm{NO}_{2}$ concentration, indicate that if reaction (4) is the source of HONO in these chambers it must occur heterogeneously. Indeed, from the data of Sakamaki, Hatakeyama, and Akimoto [14] an upper limit of $k_{4} \leqslant 1.8 \times 10^{-38} \mathrm{~cm}^{6}$ molecule ${ }^{-2} \mathrm{~s}^{-1}$ (lower than that derived above) can be obtained for the homogeneous third-order rate constant. This value then makes the homogeneous reaction (4) totally negligible in our experiments.

There are at least three possible mechanisms which are consistent with our experimental data. In the first two, reaction (5) is the rate determining step, followed by either reaction (4) or reactions (6) and (7)

$$
\begin{gathered}
\mathrm{NO}_{2}{ }^{\text {gas }} \stackrel{\text { slow }}{\longrightarrow} \mathrm{NO}_{2}{ }^{\text {wall }} \\
2 \mathrm{NO}_{2}{ }^{\text {wall }}+\mathrm{H}_{2} \mathrm{O}^{\text {wall }} \stackrel{\text { fast }}{\longrightarrow} \mathrm{HONO}^{\text {wall }}+\mathrm{HNO}_{3}{ }^{\text {wall }}
\end{gathered}
$$

or

$$
\mathrm{NO}_{2}{ }^{\text {wall }}+\mathrm{H}_{2} \mathrm{O}^{\text {wall }} \stackrel{\text { fast }}{\longrightarrow}\left(\mathrm{NO}_{2} \cdot \mathrm{H}_{2} \mathrm{O}\right)^{\text {wall }}
$$

and

$$
\left(\mathrm{NO}_{2} \cdot \mathrm{H}_{2} \mathrm{O}\right)^{\text {wall }}+\mathrm{NO}_{2} \stackrel{\text { fast }}{\longrightarrow} \mathrm{HONO}^{\text {wall }}+\mathrm{HNO}_{3}^{\text {wall }}
$$

In these cases, adsorption of $\mathrm{NO}_{2}$ must be rate determining to explain 
the first-order dependence on $\mathrm{NO}_{2}$, and this adsorption onto the wall must also depend on the water vapor concentration (Fig. 3).

A third possible reaction involves rapid adsorption of $\mathrm{NO}_{2}$ onto the wall,

$$
\mathrm{NO}_{2}{ }^{\text {gas }} \stackrel{\text { fast }}{\longrightarrow} \mathrm{NO}_{2}{ }^{\text {wall }}
$$

followed by the slow formation of a surface $\left(\mathrm{NO}_{2} \cdot \mathrm{H}_{2} \mathrm{O}\right)$ complex [reaction $\left.\left(6^{\prime}\right)\right]$

$$
\mathrm{NO}_{2}{ }^{\text {wall }}+\mathrm{H}_{2} \mathrm{O}^{\text {wall }} \stackrel{\text { slow }}{\longrightarrow}\left(\mathrm{NO}_{2} \cdot \mathrm{H}_{2} \mathrm{O}\right)^{\text {wall }}
$$

The subsequent rapid reaction (7) then leads to the final products. In all cases the HONO formed on the wall will be desorbed into the gas phase.

$$
\mathrm{HONO}^{\text {wall }} \rightarrow \mathrm{HONO}^{\text {gas }}
$$

The above schemes are almost certainly oversimplifications of this system. However, until additional data are available concerning the behavior of the various nitrogen oxides and oxyacids on surfaces, further speculation concerning the details of these reactions is unwarranted.

Although $\mathrm{HNO}_{3}$ is expected to be formed as a co-product along with HONO in the hydrolysis of $\mathrm{NO}_{2}, \mathrm{HNO}_{3}$ was not observed in the gas phase either in our study or in that of Sakamaki, Hatakeyama, and Akimoto [14]. Instead, an apparent loss of gas phase nitrogen, at rates approximately corresponding to the expected rates of $\mathrm{HNO}_{3}$ formation, has been observed. Thus it appears that, unlike $\mathrm{HONO}$, if $\mathrm{HNO}_{3}$ is formed in a surface reaction such as reactions (4) or (7), it remains on the surface, being desorbed only slowly, if at all. This conclusion is consistent with recent data from our laboratories [23] that gas phase $\mathrm{HNO}_{3}$ decays to the walls in the evacuable chamber with lifetimes of ca. $13 \mathrm{~h}$ at ca. $2 \% \mathrm{RH}$ and ca.1.6 h at ca.50\% RH. Furthermore, it is possible that $\mathrm{HNO}_{3}$ adsorbed on the wall may oxidize adsorbed organics leading to the formation of NO, as observed in both our study and that of Sakamaki, Hatakeyama, and Akimoto [14].

As noted earlier, after extended periods of time the rates of HONO formation decreased (see, for example Fig. 1) and the formation of NO (presumably a secondary product) was observed. Additionally, in most runs the disappearance rate of $\mathrm{NO}_{2}$ also decreased with time, though this decrease was generally relatively less than the decrease in the HONO formation rate. The final yields of HONO, NO, and lost nitrogen for the evacuable chamber experiments in which NO was measured are summarized in Table I. It can be seen that in all cases ca.40-60\% of the $\mathrm{NO}_{2}$ reacted is lost from the gas phase and, for the 
runs performed for the longest duration, the final yield of NO approaches the final yields of HONO.

While the formation of $\mathrm{NO}$ and the reduced rate of HONO formation late in these experiments could be caused by the decomposition of HONO or by reaction of $\mathrm{HONO}$ with $\mathrm{NO}_{2}$

$$
\begin{aligned}
2 \mathrm{HONO} & \rightarrow \mathrm{NO}+\mathrm{NO}_{2}+\mathrm{H}_{2} \mathrm{O} \\
\mathrm{NO}_{2}+\mathrm{HONO} & \rightarrow \mathrm{HNO}_{3}+\mathrm{NO}
\end{aligned}
$$

the upper limits obtained in this work for $k_{-3}$ and by Streit et al. [22] for $k_{-9}$ (combined with the equilibrium constant $k_{9} / k_{-9}$ [20]) allows these homogeneous gas phase reactions to be ruled out as the source of NO.

\section{Implications Concerning Chamber Radical Sources}

As discussed in the Introduction, the dark formation of HONO from $\mathrm{NO}_{2}$, whose importance in environmental chambers had been proposed earlier $[6,7]$ and has now been established by this study and that of Sakamaki, Hatakeyama, and Akimoto [14], will contribute, at least in part, to the excess rate of radical initiation characteristic of $\mathrm{NO}_{\mathbf{x}}$-air and $\mathrm{NO}_{x}$-organic-air irradiations in environmental chambers. Thus in a recent detailed investigation of this problem [6,7], carried out in four different environmental chambers (including the evacuable chamber used in this study and an all-Tefion chamber similar to the one used here), it was concluded that "unknown" sources of $\mathrm{OH}$ radicals were present in all of the chambers studied and that two distinct radical sources were necessary to explain the data: (1) the photolysis of initially present HONO, whose importance increased with increasing $\mathrm{NO}_{2}$ / NO concentration ratios, but which was a minor contributor to the overall radical flux after $30-60 \mathrm{~min}$ of irradiation, and (2) a constant (for those $\mathrm{NO}_{x}$-air irradiations) radical source which dominated beyond the first ca.60 min of irradiation. After the first ca.30-60 min of irradiation, the radical input rates were observed to be independent of the NO concentration, to increase with increasing temperature, humidity and $\mathrm{NO}_{2}$ concentration, to be proportional to the light intensity, and to be dependent on the chamber employed [7].

The present results show that in environmental chambers significant amounts of HONO will be present at the commencement of irradiation, since environmental chamber experiments generally involve some elapsed time between the injection of $\mathrm{NO}_{2}$ and the beginning of the irradiation. The photolysis of this initially present HONO then explains the rapidly decaying radical source which is observed in such experiments. 
However, the rates of HONO formation from the dark reaction of $\mathrm{NO}_{2}$ with $\mathrm{H}_{2} \mathrm{O}$ in the evacuable chamber in this study are a factor of ca.10 smaller than the continuous radical input rates determined for this chamber [7]. Hence, the continuous production of HONO from $\mathrm{NO}_{2}$ and the subsequent photolysis of HONO can only explain ca.10\% of the unknown radical source after ca. $60 \mathrm{~min}$ of irradiation. However, it is interesting that the production of HONO in the dark has a very similar behavior to this unknown continuous radical source. Thus both increase linearly with the $\mathrm{NO}_{2}$ levels, neither are affected by changes in the NO concentration, and both increase with the water vapor concentration. These facts strongly suggest that the interaction between $\mathrm{NO}_{2}$ and $\mathrm{H}_{2} \mathrm{O}$ and the chamber walls, which are responsible for dark HONO formation, could also be involved in the production of radicals during the irradiations. However, the details of this process remain elusive at present.

\section{HONO Formation in Polluted Atmosphere}

The fact that HONO is observed to continuously increase at night in urban atmospheres (up to ca. 8 ppb near downtown Los Angeles) when $\mathrm{NO}_{2}$ and (frequently) NO levels are relatively constant $[4,8]$ is strongly suggestive that HONO is formed in the atmosphere through one or more chemical reactions. However, in view of our direct measurements of HONO in auto exhaust [10] it is also possible that the observed nighttime increase in HONO may be due, at least in part, to direct emissions.

Recently Stockwell and Calvert [9] have postulated that HONO is formed in nighttime atmospheres from the reaction of $\mathrm{HO}_{2}$ radicals with $\mathrm{NO}_{2}$ [reaction (10)].

$$
\mathrm{HO}_{2}+\mathrm{NO}_{2} \rightarrow \mathrm{HONO}+\mathrm{O}_{2}
$$

Although there are a variety of sources of $\mathrm{HO}_{2}$ radicals at night, Stockwell and Calvert [9] concluded, based upon a chemical computer modeling study and, in the absence of experimental data, using an $\mathrm{HCHO}$ concentration of $20 \mathrm{ppb}$, that the major source of $\mathrm{HO}_{2}$ radicals arises from reaction (11) followed by reaction (12), which is rapid in one atmosphere of air.

$$
\begin{gathered}
\mathrm{NO}_{3}+\mathrm{HCHO} \rightarrow \mathrm{HNO}_{3}+\mathrm{HCO} \\
\mathrm{HCO}+\mathrm{O}_{2} \rightarrow \mathrm{HO}_{2}+\mathrm{CO}
\end{gathered}
$$

In the absence of experimental data, the rate constant $k_{11}$ was assumed [9] to be equal to that for the reaction of $\mathrm{NO}_{3}$ radicals with $\mathrm{CH}_{3} \mathrm{CHO}$ $\left(1.4 \times 10^{-15} \mathrm{~cm}^{3}\right.$ molecule ${ }^{-1} \mathrm{~s}^{-1}$ at $300 \mathrm{~K}$ [24]). While the assumed 
$\mathrm{HCHO}$ level of $20 \mathrm{ppb}$ is consistent with late evening measurements reported by Grosjean [25], recent measurements in this laboratory [26] have shown that $k_{11}=3.2 \times 10^{-16} \mathrm{~cm}^{3}$ molecule ${ }^{-1} \mathrm{~s}^{-1}$, a factor of 4 lower than that assumed by Stockwell and Calvert [9]. Thus the reaction sequence (10)-(12) seems unlikely to be a significant formation route to nighttime HONO under typical ambient conditions.

Based on the available data, it appears that a combination of direct HONO emissions [10] and heterogeneous formation via the hydrolysis of $\mathrm{NO}_{2}$ are responsible for the formation of HONO at night. Indeed, the HONO formation rate observed in the SAPRC 5800-L evacuable chamber at ca. $300 \mathrm{~K}$ and ca. $50 \% \mathrm{RH}$ leads to the formation of ca.5 ppb of HONO over an 8-h time period. While perhaps fortuitous, since in general one would expect rates of heterogeneous processes to vary greatly with different surfaces, this level falls within the range of maximum HONO levels of ca.2-8 ppb we have observed in urban atmospheres by DOAS $[4,8]$, suggesting that such a heterogeneous process may be the mechanism predominantly responsible for nighttime HONO formation.

\section{Acknowledgment}

The authors gratefully acknowledge the financial support of the U.S. Environmental Protection Agency Grant No. R807739 and thank Mr. William D. Long for assistance in conducting the chamber experiments, Dr. Barbara J. Finlayson-Pitts for helpful discussions, and Dr. Jack J. Treacy for experimental contributions in the initial stages of this program.

\section{Bibliography}

[1] W. R. Stockwell and J. G. Calvert, J. Photochem., 8, 193 (1978).

[2] K. L. Demerjian, J. A. Kerr, and J. G. Calvert, Adv. Environ. Sci. Technol., 4, 1 (1974).

[3] B. J. Finlayson-Pitts and J. N. Pitts, Jr., Adv. Environ. Sci. Technol, 7, 75 (1977).

[4] G. W. Harris, W. P. L. Carter, A. M. Winer, J. N. Pitts, Jr., U. Platt, and D. Perner, Environ. Sci. Technol., 16, 414 (1982).

[5] R. Atkinson and A. C. Lloyd, J. Phys. Chem. Ref. Data, in press.

[6] W. P. L. Carter, R. Atkinson, A. M. Winer, and J. N. Pitts, Jr., Int. J. Chem. Kinet., 13, 735 (1981).

[7] W. P. L. Carter, R. Atkinson, A. M. Winer, and J. N. Pitts, Jr., Int. J. Chem. Kinet., 14, 1071 (1982).

[8] U. Platt, D. Perner, G. W. Harris, A. M. Winer, and J. N. Pitts, Jr., Nature (London), 285, 312 (1980).

[9] W. R. Stockwell and J. G. Calvert, J. Geophys. Res., 88, 6673 (1983).

[10] J. N. Pitts, Jr., H. W. Biermann, E. C. Tuazon, and A. M. Winer, Atmos. Environ., in press. 
[11] W. P. L. Carter, A. C. Lloyd, J. L. Sprung, and J. N. Pitts, Jr., Int. J. Chem. Kinet., 11, 45 (1979).

[12] W. H. Chan, R. J. Nordstrom, J. G. Calvert, and J. H. Shaw, Environ. Sci. Technol., 10, 674 (1976).

[13] W. H. Chan, R. J. Nordstrom, J. G. Calvert, and J. H. Shaw, Chem. Phys. Lett., 37, 441 (1976).

[14] F. Sakamaki, S. Hatakeyama, and H. Akimoto, Int. J. Chem. Kinet., 15, 1013 (1983).

[15] E. W. Kaiser and C. H. Wu, J. Phys. Chem., 81, 1701 (1977).

[16] C. England and W. H. Corcoran, Ind. Eng. Chem. Fundam., 13, 373 (1974).

[17] Y.-N. Lee and S. E. Schwartz, J. Phys. Chem., 85, 840 (1981).

[18] A. M. Winer, R. A. Graham, G. J. Doyle, P. J. Bekowies, J. M. McAfee, and J. N. Pitts, Jr., Adv. Environ. Sci. Technol., 10, 461 (1980).

[19] G. J. Doyle, P. J. Bekowies, A. M. Winer, and J. N. Pitts, Jr., Environ. Sci. Technol., 11, 45 (1977).

[20] S. E. Schwartz and W. H. White, Adv. Environ. Sci. Eng., 4, 1 (1981).

(21] E. W. Kaiser and C. H. Wu, J. Phys. Chem., 81, 187 (1977).

[22] G. E. Streit, J. S. Wells, F. C. Fehsenfeld, and C. J. Howard, J. Chem. Phys., 70, 3439 (1979).

[23] E. C. Tuazon, R. Atkinson, C. N. Plum, A. M. Winer, and J. N. Pitts, Jr., Geophys. Res. Lett., 10, 953 (1983).

[24] E. D. Morris, Jr., and H. Niki, J. Phys. Chem., 78, 1337 (1974).

[25] D. Grosjean, Environ. Sci. Technol., 16, 254 (1982).

[26] R. Atkinson, C. N. Plum, W. P. L. Carter, A. M. Winer, and J. N. Pitts, Jr., J. Phys. Chem., 88, 1210 (1984). 